\title{
Students' participation in university governance and organizational effectiveness in Ekiti and Ondo states, Nigeria
}

\author{
Dr. (Mrs.) Akomolafe, C.O and Mrs. Ibijola, E.Y \\ Department of Educational Foundations and Management, University of Ado-Ekiti, Nigeria \\ ABSTRACT
}

\begin{abstract}
This study investigated students' participation in university governance and the organizational effectiveness in Ekiti and Ondo State of Nigeria. The variables concerned were, level of students' participation in university governance, level of organizational effectiveness and the relationship between students' participation in university governance and organizational effectiveness. A descriptive research of survey design was adopted for the study. The population for the study consisted of the staff and students of the University of Ado-Ekiti and Adekunle Ajasin University, Akungba Akoko. Five hundred (500) students and two hundred (200) members of staff were selected through stratified and simple random techniques. Data were collected with an instrument titled 'Questionnaire on Students' Participation in University Governance and Organizational Effectiveness (SPUGOE). The instrument was validated with a reliability coefficient of 0.93 and subsequently administered on the subjects. Simple percentage was employed to analyse the data and answer the research questions while the hypothesis raised was tested using Pearson product moment correlation technique. The result was held significant at 0.05 level. The findings of the study revealed a moderate level of students' participation in university governance and a moderate level of organizational effectiveness. A significant relationship between students' participation in university governance and organizational effectiveness in the university system was established. Therefore students' participation in university governance is an important factor in organizational effectiveness in the university system. Based on the findings of this study, conclusions were drawn. It was recommended that students should be well represented on all university statutory committees including senate and council committees to enhance level of organisational effectiveness in the system. It was also recommended that the number of students representatives on all statutory committees be increased.
\end{abstract}

\section{INTRODUCTION}

Education is the bedrock for any meaningful development in any nation. This view point was corroborated by many authors and researchers. According to Ayodele (2005), investment in human capital has over the years been recognized to be the bedrock of increased productivity and enhanced economic development. This view was buttressed by Musa (2007) who also viewed education as the bedrock of any human endeavour in achieving the developmental process of any country. Despite the importance attached to education, especially university education in Nigeria, it is today faced with a lot of crises situations. Mennon(2003) citing Bamelt opined that contemporary universities face difficulties in meeting the demands and expectations of their public, leading to what has been described as a crisis in higher education. Supporting this view, Ibukun (1997) viewed university governance in Nigeria today as crises management.
The crises situations in Nigerian universities today, have not been unconnected with the incessant staff union strikes (ASUU, SSANU, NASU and NAAT) and the frequent students protest usually in the form of violent demonstrations Eige (1994). This situation has led to perennial closure of the university system such that most of the academic calendars approved by senates of most Nigerian universities are no longer strictly followed. Indeed, having a unified academic calendar in Nigerian Universities is gradually becoming history. In the recent past, it was observed that a whole academic session (2003/2004) academic session was cancelled by the senate of the University of Ado-Ekiti following a cumulative effect of prolonged irregular academic sessions.

The concepts of effective organization and good corporate governance according to Tajomavwo (2009) have much in common and have received considerable attention in recent years. According to him, an effective organization is one that is able to achieve goals or results, and is able to meet its 
obligation to all stakeholders, now and in the distant future. Beehr and Newman (1998) asserted that Organizational effectiveness is the concept of how effective an organization is in achieving the outcomes the organization intends to produce. The irregular academic calendars in the Nigerian Universities have led to decline in productivity. The funding problems in the system not withstanding, a five year budgetary allocation or more could be spent on a four year programme. There is time reduction in the teaching and learning process. Students are only sure of date of admission, expected year of graduation is no longer known from inception. Parents/Guardians now incur extra cost keeping their children/wards indefinitely in school. The irregular academic calendar has also encouraged examination malpractices, cultism and other vices on Nigerian Universities campuses. All these put together according to Ayodele (2005) are educational wastages which have rendered the university system ineffective.

The issue of half baked and the unemployability status of the Nigerian graduates which have been a point of discourse among educationalists and debated both in the print and electronic media today has been another perceived resultant effect of the unstable academic calendar. This was rightly observed when Oto (2006) opined that major employers of Nigerian graduates have widely agreed on quality decline in high education in the country, particularly in the areas of communication in oral and written English and technical proficiency. Corroborating this view, Imogie cited in Ogideta (2008) stressed that if education must serve the society, it must produce people who carry more than certificates.

However, the events of the past decades tended to suggest that the system of governance of the Nigerian universities needed a change for good. Research on students participation in institutional governance according to Mennon and Persson cited in Olayiwola (2001) showed that students in general experience lack of participation. Eye cited in Adesanoye (2000) asserted that of all the important reference groups within the school, students are the least involved in the making of major educational decisions. The organization consists of individuals with varying needs, interest, values, personalities, opinions and ideologies. Therefore, conflict in organizations can be seen as a by-product of group dynamics. Conflicts in Organization is inevitable Ajayi and Ayodele (2002). Ibukun (1997) believed that "conflict is natural and normal. On this premise, Ikenwe(1998), highlighting the work of Foxworthy, wrote that the primary motive of instituting the committee system in institutional governance has grown out of the motive concern for democratizing decision making in those institutions and a recognition of the need for more broadly based decision making as universities become more complex on the premise. In the management of higher institutions therefore, committees play very important roles in the decision making process. This is because as democratic establishment, universities' decisions must reflect the opinion of a cross section of the staff and students, if such decisions are to be accepted. This view point was supported by Longing (2002).

Literature revealed that, the issue of effectiveness in the university administration should be seen as a joint responsibility of both staff and students. According to ezekwem(2009), the impact of the students union government in instilling discipline among students populace cannot be over emphasized. The new market orientation adopted by tertiary institutions in their attempt to survive in an increasing competitive higher education arena is associated with a "customer" focus in educational planning and decision - making (Jones, Shan Isan and Goyan) cited in Adesanoye (2000). In this context, students' union representatives are allowed to serve as members on some of these universities' committees. At the University of Ado-Ekiti for instance, the regulation governing it allows for students representatives to serve as members on the following university committees; the students' disciplinary committee; where students who breached their matriculation oaths are tried and punished accordingly. The security committee, the students electoral committee, ceremony committee and sports committee among others.

In the same vein, at the Adekunle Ajasin university, Akungba-Akoko, the university regulation allows that students' union government be represented on some university committees such as students' welfare committee, sports committee, ceremony committee, students' disciplinary committee and environmental committee. It is observed that the participation of students on these committees is to make the student body have a sense of belonging and most especially to see themselves as part of the decision making process in the university system. Akomolafe (2002) opined that participation in decision making gives the 
participants greater feelings of self-direction and has a positive relationship with motivation.

In this connection, the Researchers would want to investigate the level of students' participation in university governance and the level of organizational effectiveness and what more could be achieved by further involving student in all university statutory committees with the purpose of bringing to the barest minimum issues resulting into crises leading to perennial closure of the system.

Statement of the problem: It has been observed for some years past that, universities academic calendars no longer run from October to September. Most universities often amend their academic calendars severally to suit the prevailing situations. At the University of Ado-Ekiti for instance, 2003/2004 academic year was cancelled following a prolonged cummulative effect of irregular academic sessions. The academic year was so much irregular to the extent that the university as at that time had two sets of universities matriculation examination (UME) admissions; on her hands. This has resulted into students over staying in school. By implication, this is an educational wastage according to Ayodele (2005).

This in the long run could result in half-baked and unemployable graduates. There would be decline in productivity in the university system as outputs (students) are kept static while inputs (human and material resources) increase. Manya (2009) defined Productivity as a performance measure that indicates how effectively an organization converts its resources into its desired products or services. In other words, productivity indicates how well an organization transforms its inputs into outputs.

Based on the aforementioned problems, the study therefore investigated the level of students' participation in university governance, the level of organizational effectiveness in the system, and the relationship between students' participation in university governance and organizational effectiveness.

\section{Research questions}

i. What is the level of students' participation in university governance?

ii. What is the level of organizational effectiveness in the University system?

\section{Research Hypothesis}

i. There is no significant relationship between students' participation in university governance and organizational effectiveness in the University system.

\section{Research Method}

This study employed a descriptive research of survey type. Descriptive research design was considered appropriate because it focused on the observation of perception of the existing situation. The population for the study consisted of all staff and students of the University of Ado-Ekiti, Ekiti-state and Adekunle Ajasin University, Akungba-Akoko, Ondo-State

There were 1,743 members of staff and 14,652 students in the university of Ado-Ekiti while there were 587 members of staff and 10,580 students at Adekunle Ajasin University, Akungba Akoko. The overall population was 27,562 . The sample for the study was made up of 700 subjects, consisting of 50 students' union executive members, 200 students, 50 top university administrators, and 50 lecturers from each of the two universities covered by this study. Stratified random and simple random sampling techniques were used to select the samples. The population was divided into strata based on the groups within the university, while simple random sampling technique was used to select the samples from each stratum. These sampling techniques were able to cater for the sub-groups of interest within the population.

The instrument used to collect data was a structured questionnaire titled "Questionnaire on Students' Participation in University Governance and Organizational Effectiveness (SPUGOE)". In order to ensure the face and content validity of the instrument, it was validated by experts in Test and Measurement in the Faculty of Education, University of Ado-Ekiti. To ascertain the reliability of the instrument, the splithalf method was used, that is, the study utilized the scores from a single test to estimate the consistency of the test items. The odd number items and even number items were scored separately. A reliability coefficient of 0.90 was obtained using the Pearson $r$ correlation analysis. The co-efficient was corrected to full-length coefficient using the Spearman Brown prophecy formular. The resulting co-efficient was 0.93 .

The data obtained from the instrument were analyzed. Simple percentage was employed to analyze the data descriptively hence the two 
research questions were answered. The research hypothesis was tested using Pearson correlation technique. The hypothesis was tested at 0.05 level of significance.

\section{RESULTS AND DISCUSSION}

\section{Research Question 1:}

What is the level of students' participation in university governance?

The findings in respect of this question are summed up in table 1 and figure 1

Table 1: Level of students' participation in university governance.

\begin{tabular}{|l|l|l|}
\hline $\begin{array}{l}\text { Level of students' participation in university } \\
\text { governance }\end{array}$ & $\mathrm{f}$ & $\%$ \\
\hline Low (41-58.20) & 118 & 16.9 \\
\hline Moderate (58.3-81.57) & 462 & 66.0 \\
\hline High (81.58-100) & 120 & 17.1 \\
\hline
\end{tabular}

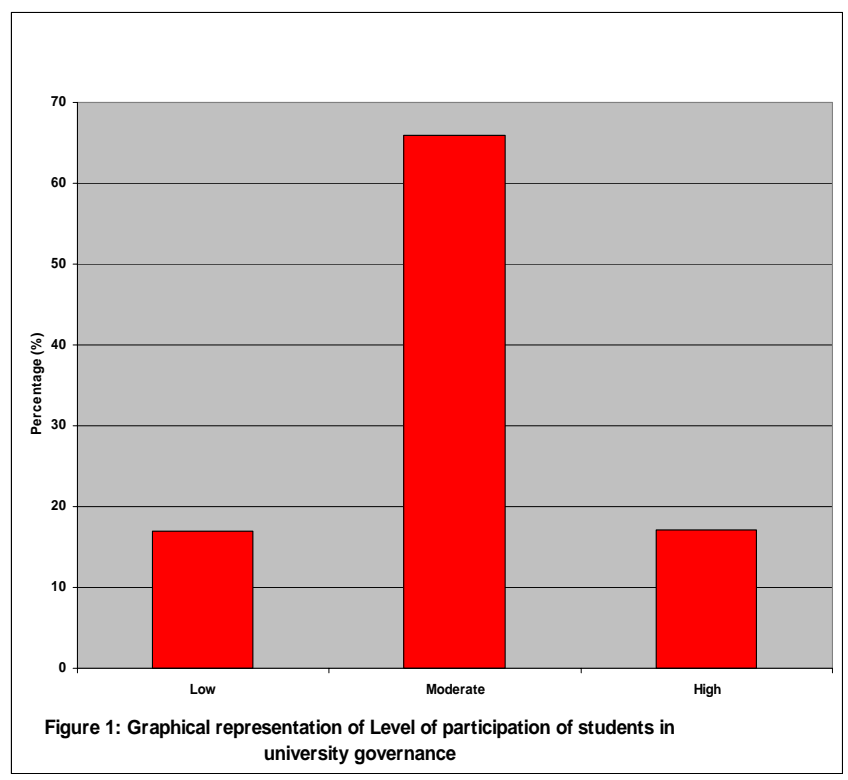

Table 1 and Figure 1 revealed that the level of students' participation in university governance is moderate. Analysis of the result showed that $118(16.9 \%)$ of the respondents agreed to low level of participation while 462(66\%) and $120(17.1 \%)$ agreed to "moderate" and "High" levels of student' participation, in university governance respectively.

\section{Question 2}

What is the level of organizational effectiveness in the university system?

The findings in respect of this question is presented in the Table 2 and figure 2 below

Table 2: Level of Organizational Effectiveness in the University system

\begin{tabular}{|l|l|l|}
\hline Level of organizational effectiveness & $\mathrm{f}$ & $\%$ \\
\hline Low (33-63.57) & 131 & 18.7 \\
\hline Moderate (63.58-82.88) & 457 & 65.3 \\
\hline High (82.89-100) & 112 & 16.0 \\
\hline
\end{tabular}

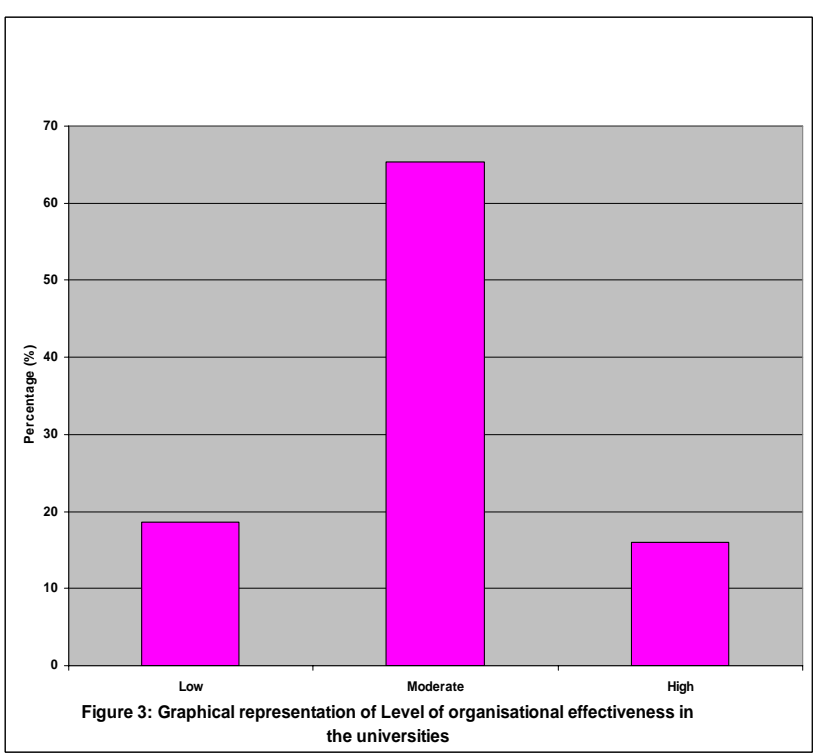

Table 2 and Figure 2 showed that the level of organizational effectiveness is moderate. The result showed that 131 respondents i.e (18.7\%) adjudged the level of organizational effectiveness as low, while $457(65.3 \%)$ and $112(16.0 \%)$ saw it as "moderate" and "high" respectively.

\section{Hypothesis 1.}

There is no significant relationship between students' participation in university governance and organizational effectiveness in the university system. 
Table 3: Pearson correlation analysis on relationship between students' participation in university governance and organizational effectiveness.

\begin{tabular}{|l|l|l|l|l|l|}
\hline Variable & N & $\bar{X}$ & SD & r-cal & r-table \\
\cline { 1 - 4 } Students' participation & 700 & 69.89 & 11.69 & & \\
\cline { 1 - 4 } Organizational effectiveness & 700 & 72.73 & 10.16 & \multirow{2}{*}{$0.551^{\star}$} & 0.195 \\
\hline
\end{tabular}

$\mathrm{P}<0.05$

Table 3 shows that $r$-cal value of $(0.551)$ is greater than r-table value of $(0.195)$ at 0.05 level of significance. The null hypothesis was rejected. Therefore, there was a significant relationship between students' participation in university governance and organizational effectiveness in the university system.

\section{DISCUSSION}

The findings of this study revealed that the level of students' participation in university governance was moderate. This was an indication that students' participation in university governance was on the average. The finding however, negates Adesanoye (2000) who asserted that of all the important reference groups within the school, the students were the least involved in the making of major educational decision. It also negates Nwankwo cited in Olayiwola (2001) who asserted that students play a passive role in institutional governance as their attendance on any university committee was very insignificant to decisions made.

This study revealed that the level of organizational effectiveness was moderate. This implies inefficiency in the system. According to Ayodele (2005), Beehr and Newman (1998) asserted that organizational effectiveness is the concept of how effective an organization is in achieving the outcomes the organization intends to produce. In this connection, the moderate level of organizational effectiveness established by the study is an indication of inefficiency in the system.

The study revealed a significant relationship between students' participation in university governance and organizational effectiveness in the university system. The commensurate level of students' participation in university governance with the level of organizational effectiveness implies that student's participation in educational decision making process would enhance higher level of institutional effectiveness. This finding supported Adesanoye (2000) who submitted that, enhancement of control by rank and file members is deemed essential for increasing organizational effectiveness, since involvement in decision making within the context of a democratic culture appears necessary to foster conditions of human identification, motivation and loyalty.

\section{RECOMMENDATIONS:}

Based on the findings of the study, the following recommendations were made;

1. Management should allow students' representatives to serve as statutory members in all statutory university committees, senate and council inclusive.

2. There should be an upward review of the member of students representatives on each committee in the university system.

3. Management should ensure that students' contributions at meetings count in decision making process.

4. Government at all levels should encourage students' participation in university governance by allowing representatives of the National Association of Nigerian Students (NANS) to serve on all federal and state committees on university education, bursary and scholarship boards inclusive.

\section{CONCLUSION:}

The moderate level of students' participation in university governance as revealed by the study was an indication that students do take part in university governance but at a moderate level. However, the commensurate level of students' participation in university governance and the level of organizational effectiveness established in the study, confirms the significant relationship between the two variables. 


\section{REFERENCES}

Adesanoye, A. P. (2000); A study of Students participation in School Management. A case study of some Secondary Schools in Ikale Local Government Area of Ondo State; An unpublished M.Ed Thesis. O.A.U. IleIfe.

Ajayi I. A. and Ayodele J. B. (2002); Fundamentals of Educational Management; Greenline Publishers, Odoljigbo Street, Ado-Ekiti.

Akomolafe C. O. (2002); Principals' behaviour and staff development in Ekiti State Secondary Schools. Unpublished Ph.D. thesis.

Ayodele, J.B. (2005); Fundamentals of Systems Analysis in Education. Ikeja, Lagos, Bolabay Publications.

Beehr, T. and Newman, J.E. (1998); Job Sress, Employee Health and Organizational EffectivenessRetrived from;

http://www.nga.org/files/pdf/0602creatinghealthystatew ork.pdf. on 04/05/08

Eige, B, (1994); Sources of Conflict within Nigeria Universities - Proceedings of the $8^{\text {th }}$ General Assembly of the Social Sciences Council of Nigeria.

Ezekwem, C. C. (2009); Students Unionism and University Administration in Nigeria Retrievedfrom http://u08cgpublisher.com/proposals/368/index.html. on $24 / 03 / 10$

Ibukun, W. O. (1997); Educational Management. Theory and practice. Ado-Ekiti, Bangboye and Company Press, Nigeria Limited.

Ikenwe J.O. (1998); The use of commitee in the state schools; An unpublised Thesis. University of Nsukka.
Longing T.C. (2002); Institutional governance: A call for collaborative decision making in America higher education. Baston, MA Anker Publishing Co.

Manya, D. (2009); Enhancing Organizational Productivity; A paper delivered at the Workshop on Enhancing Organizational Change and Effectiveness; Centre for Management Development, Shangisha, Lagos.

Menon, M.E (2003); Student involvement in university governance; A need for negotiated educational aims? Springer Netherland Publishers. Volume 9 number 3. Pp 233-246.

Musa, J. A. (2007); Relationship between job satisfaction and work performance of teachers in secondary schools in Akure Local Government Area of Ondo State. Unpublished M. Ed. Thesis, University of AdoEkiti, Nigeria.

Ogideta, I. (2008); Examination Malpractices in Educational Institutions in Nigeria: Implication for the counselor; Retrieved from: http://transformedu.org/linkclick.aspx?fileticket. 14/07/09

Olayiwola, O. (2001); "Students' Participation in Secondary School Administration in selected Schools of Irewole Local Government Area, Oyo-State" Unpublished M.Ed. thesis, O.A.U. Ile-Ife.

Oto, J. O. (2006); A Critique of Students' Vices and the Effect on Quality of Graduates of Nigerian Tertiary Institutions. Retrieved from www.krepublishers.com. On 17/09/09

Tajomavwo, G. A. (2009); Characteristics of Effective Organization; A paper delivered at a Workshop On Enhancing Organizational change and Effectiveness; Centre for Management Development, Shangisha, Lagos. 